\title{
Labour relations in comparative perspective - special focus on the SME sector (Part II) ${ }^{*}$
}

\author{
Csaba Makó, Péter Csizmadi, Miklós Illéssy ${ }^{* *}$
}

The evolution of the view and practice of "social partnership" is one basic element in the construction of the European Union. The paper gives an overview on the key actors and institutions of Labour Relations System (LRS) with special focus on the micro- small and medium sized enteprises (SME). In the first section, the author describes the key social partners and institutions of the LRS in the countries participating in an international research project carried out in 2003-2006. The second section of the paper deals with the particular features of the LRS in the SME sector. The strong "informality" of social dialogue is the key institutional pattern of LRS in the SME sector.

Die Evolution der Betrachtung und Anwendung von „sozialen Partnerschaften" ist ein Basiselement für die Entwicklung der Europäischen Union. Dieser Aufsatz gibt einen Überblick über die Hauptakteure und Institutionen des Systems der industriellen Beziehungen (IB), mit einem speziellen Augenmerk auf kleine und mittelständische Unternehmen (KMU). Im ersten Abschnitt beschreibt der Autor die wichtigsten sozialen Partner und Institutionen der IB in den Ländern, die 2003-2006 an einem internationalen Forschungsprojekt teilnahmen. Der zweite Teil behandelt die spezifischen Eigenschaften des IB im KMU-Sektor. Die ausgeprägte „Informalität" des sozialen Dialogs ist ein wichtiges institutionelles Muster der IB im KMU-Sektor.

Key words: LabourRelations System, Social Actors and Institutions, Collective Bargaining, Works Council, Informal Regulation, SME

\footnotetext{
Manuscript received: 20. 01. 06, accepted: 11.04.06(1 revision)

** Csaba Makó, Research Director, Institute of Sociology Hungatian Academy of Sciences, Budapest. Main research areas: Organisational-institute innovations and learning process, labour relations in international perspective and the emerging new patterns of work organisation and management related to the use of ICT. Corresponding address: Mako@socio.mta.hu

Péter Csizmadia, Research Associate, Institute of Socioogy of the Hungarian Academy of Sciences; PhD-student, Department of Sociology and Social Policy,Corvinus University, Budapest. Corresponding address: pcsizmadia@socio.mta.hu.

Miklós Illéssy, Research Associate, Institute of Sociology of Hungarian Academy of Sciences; PhD-student, Department of Sociology and Social Policy, Corvinus University Budapest. Corresponding address: 1llessy@socio.mta.hu.
} 


\section{Foreword}

The aim of the project supported by the Leonardo programme of the European Commission was to develop a research-based international comparative training curriculum about the SME sectors in eight European participant countries: Belgium, France, Germany, Hungary, Poland, Slovakia, Spain and the UK. The results of the fist project phase is summarised in a Comparative Report (CR). This analysis is focusing on the such social regulatory institutions of firms' behaviour as the Labour Relations System (LRS).2. Sources and forms of a firm's competitive advantage - literature review.

\subsection{National level concertation and consultation institutions}

The review of the various coordination forms of wage bargaining calls attention to the active role of national governments in influencing the outcomes of these bargaining. Evaluating the degree of government intervention in wage bargaining, we used the following 5-point scale measurement (Industrial Relations in Europe, 2005: 52.). ${ }^{1}$ Assessing the degree of government intervention in wage bargaining in the Leonardo countries, the results show considerable variations. The highest scores were reached in Belgium (4.1) and in France (3.1), followed by Hungary (3.0). The lowest level of government intervention was registered in such countries as the UK (1.2), Germany (1.9) and Spain (1.9). The scores on government intervention are occupying the middle position in Poland (2.5) and in Slovakia (2.5). Due to the important regulatory role of the statutory minimum wages ${ }^{2}$, it is important to know which countries have such a practice. All EU-15 countries involved in the Leonardo project now have a minimum wage. In Belgium, minimum wage is set by national level collective agreements but in the other countries (France, Spain, UK), the minimum wage is regulated by law. Similarly to the EU-15 countries, a statutory

1 The five-point scale proposed by the report is as follows: 5 = government imposes private sector wage settlements or suspends bargaining (involuntary wage freeze); 4 = government participates directly in private sector wage-bargaining and provides norms or ceilings, or tax-based compensation to achieve particular outcomes (social pacts); 3 = government determines wage bargaining outcomes indirectly through minimum wage-setting, wagesetting in the public sector, or through threats of sanction (for instance, withholding extension or recognition); 2 = government sets minimum wage and provides institutional framework for national or sectoral collective bargaining (legal protection of agreements, extension), consultation or dialogue (recognition and consultation). (1.5 if only one of these applies); 1 = no role of government in wage-setting. (Industrial Relations in Europe, 2004: 50.)

2 'The (statutory) national minimum wage is can also be seen as a form of coordination, since it functions as a reference point for the whole wage system.' (Industrial Relations in Europe, 2004: 51.) 
minimum wage was adapted in all new Member States (Hungary, Poland, Slovakia).

The unions' and employers' national level representative bodies dealing with consultation may take the form of bipartite, tripartite or a wider membership. As concerning their function, they may have the following roles:

1. Advisory role

2. Consultative or negotiating role

3. Standard setting function

In relation to the various roles of this consultation bodies, we have to stress the particular situation related to the tripartite consultation in the post-socialist countries participating in the Leonardo project. Without exception, in theses economies the tripartite consultation and representation became institutionalised either on the eve or on the aftermath of the democratisation process. For example, the Hungary's OÉT - National Interest Reconciliation Council - was established in 1987. In the case of Poland, the national forum for social dialogue 'Tripartite Commission for Social and Economic Issues' was established in 1994. In Slovakia, the tripartite dialogue between the social partners (state, trade unions and employers' association) has been operating for more than a decade. In the EU-15 countries the presence of the national bodies for consultation and representation is general. However, in the majority of cases, participation in such structures is practiced by national peak association of both trade unions and employers' organisations. ${ }^{3}$ These statutory bodies which could be bipartite, tripartite, etc. have a role to deal with either general issues (Belgium, Hungary) or specific issues like social security administration (e.g. France, Germany) or the application of labour law and the extension of collective agreements (as this is the case in Germany). The next table provides a list of tripartite bodies in the Leonardo countries.

\subsection{A highly sensitive feature of the labour relations: industrial actions}

The number of strikes, lock-outs, sabotage, etc. as various forms of industrial action is one of the most high-profile characteristics of industrial relations. Beside the very intensive media coverage or public attention, the intensity of the industrial action - measured by working days lost, number of employees involved, number of industrial disputes, etc. - is an important indicator of whether or not labour relations systems are functioning. The intensity of industrial actions in itself does not reflect automatically the mal-functioning but

3 Note: trade unions officers and employer representatives in the UK are appointed not as official representatives of their associations, but as 'competent individuals'. (Industrial Relations in Europe, 2004: 53.) 
according to the other features of employment relations it may reflect even a well-functioning system. For example, in the later part of this section, we will present surprisingly low level of industrial action measured by working day lost by strikes per 1,000 employees in Germany (4.0) and ion Poland (2.1). Despite the low level of this indicator, the explanatory factors are rather different. In the first case (Germany), this could be attributed to the regulated nature of the coordinated market economy, while in Poland this phenomenon could be a consequence of two interrelated factors. On the one hand deterioration of the employees' labour market position (two digits unemployment level), and on the other hand the radically weakened positions of trade unions.

Table 11. Participation of unions and employers in tripartite bodies

\begin{tabular}{|l|l|}
\hline Belgium & \multicolumn{1}{|c|}{ Tripartite bodies } \\
National Labour Council (CNT/NAR); various bodies at sectoral and regional \\
level
\end{tabular}

Source: Database of the Institut des Sciences du Travail of the Universite Catholique de Louvain (1997-2003) on behalf of the Employment and Social Affairs DG of the European Commission. Quoted by Industrial Relations in Europe, 2004: 54. Table 11. is an edited version of the original one containing data only for countries involved in the Leonardo Project.

The highest rate of working days lost by industrial action per 1,000 employees was registered in Spain (219.7) and followed by Hungary (60.2), France (40.5) and the UK (27.5). (See in details Table 12 and Figure 1.)

Table 12 highlights the following notable points:

1. The very low level of industrial action - even absence in some years - in some of new Member States (Hungary, with the exception of the year 2000 and Poland) and in such EU-15 country as Germany.

2. Very different patterns were registered in the broadly comparable (in size terms) 'big four' old European States like France, Germany, Spain and in the UK. Spain shows considerably higher level of industrial action than France, the 
UK and Germany. Though Spain appears to have experienced a rapid decline in working days lost by strikes from 2002 to 2003 and the fall further continues.

3. The lack of any consistent trend in the majority of countries characterised by figures often rising and falling from year to year.

Figure 1. Working days lost through industrial action per 1,000 employees in countries participating in the Leonardo project (Source: EIRO, 2005, p. 9.)

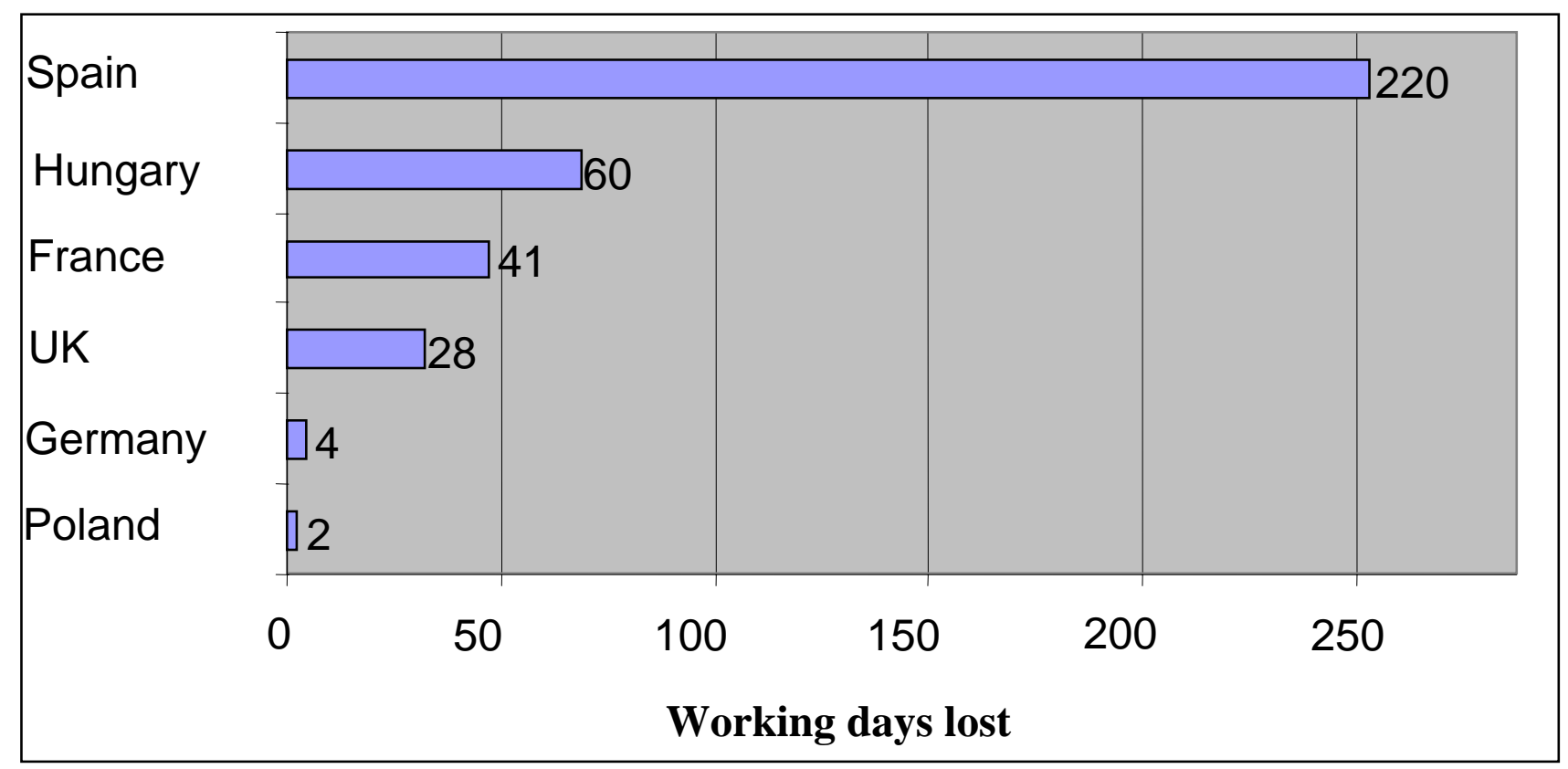

Table 12. Working days lost through industrial action

\begin{tabular}{|l|l|l|l|l|l|}
\hline Country & 2000 & 2001 & 2002 & 2003 & $2004^{*}$ \\
\hline Belgium & $n . d$. & $n . d$. & 17.6 & $n . d$. & $n . d$. \\
\hline France & 54.0 & 45.0 & 32.0 & 31.0 & $n . d$. \\
\hline Germany & 0.3 & 0.8 & 9.6 & 5.1 & 1.6 \\
\hline Spain & 292.5 & 151.0 & 377.1 & 58.1 & 35.6 \\
\hline UK & 20.0 & 20.0 & 51.0 & 19.0 & 34.0 \\
\hline Hungary & 236.0 & 4.0 & 0.4 & 0.3 & 3.0 \\
\hline Poland & 7.4 & 0.4 & 0 & 0.7 & $n . d$. \\
\hline
\end{tabular}

*In some cases, extrapolations from partial figures only - see notes.

Source: EIRO 2005: 7.

Another important characteristic of industrial action is that it does not spread evenly through the various sectors of the economy. Reviewing the three sectors most affected by industrial action (from 2000-2004) we get the following picture. The sectors most affected by industrial action were 'transport and communication' (with railways often playing a leading role) and 'manufacturing' (with metal working playing a prominent role). The 'public sector' in a broad sense (especially health care and social work, and education) 
follows closely the two first sectors. It is interesting to note that in Spain the 'construction industry' plays a major role in industrial action following the key role of this sector in the Spanish economy. According to international experiences, private sector services are rarely involved in the top three sectors in the majority of countries. In Germany too, the 'commerce-retail' sector did not figure among the sectors most affected by industrial action. Unfortunately, the statistical data on industrial action do not always allow comparison between private and public sectors (in terms of ownership). Despite this methodological shortcoming, the share of industrial action by ownership varies considerably in the countries observed. Countries where a relatively high proportion of the 'most strike-prone industries' are in the public sector include France, Hungary and the UK. Another group of countries has the most strike-affected industries in the private sector; this group includes Germany and Spain. Poland and Slovakia present a mixed-pattern of industrial action (i.e. it is not possible to clearly identify either a private or public 'dominance' in industrial action).

Evaluating the types of sectors dominating the industrial actions in a given year, we found the following syndrome. For example, a single accounted for half or more of all working days lost in: Belgium in 2002 (manufacturing); France in 2000-2001 (civil service); Germany 2001 and 2003 (manufacturing); Hungary in 2001 (non-commercial services).

Finally, it is necessary to identify the main causes of industrial actions. Evaluating the three main reasons for industrial actions in the countries participating in the Leonardo project (2000-2004), unsurprisingly, the number one reason for industrial action is unquestionably pay. It features among the leading issues in all countries, but especially in Spain. Pay is consistently the leading single issue in industrial action in France, in Hungary, in Poland and in the UK. Employment is the next most important cause for industrial action in Slovakia which could be attributed to the extremely high level (two digits) unemployment. In relation to the unemployment, we may note that dismissals are prominent in the UK, redundancies and job losses are the main source of industrial conflicts in France, Hungary and Poland. Plant closures and company's restructuring which are important reasons for industrial actions in Hungary, probably also fall under the broad heading (employment). The next most common reasons are broadly political issues concerned with generic or specific (e.g. social security, labour law reforms, privatisations and sector restructuring) government policies being the main reasons for such actions both in Slovakia and in Hungary. Political issues are often the source of industrial actions in Spain. Working time and working conditions are the last factors ranking among the motives of industrial actions in France and in the UK. Table 13 provides a general overview of reasons for industrial actions by country. 
Table 13. Main causes of industrial action in the Leonardo project's countries

\begin{tabular}{|c|c|c|c|c|}
\hline \multirow[b]{2}{*}{ Country } & \multirow[b]{2}{*}{ Year } & \multicolumn{2}{|l|}{ WEIGHT } & \multirow{2}{*}{$\begin{array}{l}\text { Effective number of } \\
\text { confederations } \\
3\end{array}$} \\
\hline & & 1 & 2 & \\
\hline Belgium & & n. $d$. & n. $d$. & n. $d$. \\
\hline \multirow{4}{*}{ France } & 2000 & Pay $(33 \%)$ & Working time $(29 \%)$ & $\begin{array}{l}\text { Working conditions } \\
(15 \%)\end{array}$ \\
\hline & 2001 & Pay $(37 \%)$ & Job losses $(21 \%)$ & Working time $(15 \%)$ \\
\hline & 2002 & Pay $(39 \%)$ & Job losses $(29 \%)$ & $\begin{array}{l}\text { Working conditions } \\
(21 \%)\end{array}$ \\
\hline & 2003 & Pay $(37 \%)$ & Job losses $(27 \%)$ & $\begin{array}{l}\text { Working conditions } \\
(20 \%)\end{array}$ \\
\hline Germany & & n. $d$. & n. $d$. & n. $d$. \\
\hline \multirow{5}{*}{ Spain } & 2000 & $\begin{array}{l}\text { Not arising from } \\
\text { collective } \\
\text { bargaining }(57 \%)\end{array}$ & $\begin{array}{l}\text { Issue not strictly linked } \\
\text { to employment } \\
\text { relationship }(24 \%)\end{array}$ & $\begin{array}{l}\text { Arising from collective } \\
\text { bargaining }(19 \%)\end{array}$ \\
\hline & 2001 & $\begin{array}{l}\text { Not arising from } \\
\text { collective } \\
\text { bargaining }(69 \%)\end{array}$ & $\begin{array}{l}\text { Arising from collective } \\
\text { bargaining }(31 \%)\end{array}$ & - \\
\hline & 2002 & $\begin{array}{l}\text { Issue not strictly } \\
\text { linked to } \\
\text { employment } \\
\text { relationship }(88 \%)\end{array}$ & $\begin{array}{l}\text { Arising from collective } \\
\text { bargaining }(6 \%)\end{array}$ & $\begin{array}{l}\text { Not arising from } \\
\text { collective bargaining } \\
(5 \%)\end{array}$ \\
\hline & 2003 & $\begin{array}{l}\text { Arising from } \\
\text { collective } \\
\text { bargaining }(63 \%)\end{array}$ & $\begin{array}{l}\text { Not arising from } \\
\text { collective bargaining } \\
(37 \%)\end{array}$ & - \\
\hline & $2004 *$ & $\begin{array}{l}\text { Arising from } \\
\text { collective } \\
\text { bargaining }(87 \%)\end{array}$ & $\begin{array}{l}\text { Not arising from } \\
\text { collective bargaining } \\
(12 \%)\end{array}$ & $\begin{array}{l}\text { Issue not strictly linked } \\
\text { to employment } \\
\text { relationship }(2 \%)\end{array}$ \\
\hline \multirow{5}{*}{ UK } & 2000 & Pay $(77 \%)$ & Redundancy (11\%) & $\begin{array}{l}\text { Staffing and work } \\
\text { allocation }(5 \%)\end{array}$ \\
\hline & 2001 & $\begin{array}{l}\text { Working conditions } \\
\text { and supervision } \\
(33 \%)\end{array}$ & Pay $(27 \%)$ & Redundancy (17\%) \\
\hline & 2002 & Pay $(89 \%)$ & $\begin{array}{l}\text { Working conditions } \\
\text { and supervision }(8 \%)\end{array}$ & Redundancy (1\%) \\
\hline & 2003 & Pay $(84 \%)$ & Working time $(13 \%)$ & $\begin{array}{l}\text { Staffing and work } \\
\text { allocation }(1 \%)\end{array}$ \\
\hline & 2004 & Pay $(84 \%)$ & Redundancy $(12 \%)$ & Working time $(2 \%)$ \\
\hline \multirow{5}{*}{ Hungary } & 2000 & Pay & Plant closures & - \\
\hline & 2001 & Pay & Plant closures & - \\
\hline & 2002 & Pay & Privatisation & Plant closures \\
\hline & 2003 & Pay & Plant closures & Job losses \\
\hline & 2004 & Pay & Privatisation & Job losses \\
\hline \multirow{2}{*}{ Poland } & 2003 & Wage arrears & Job losses & - \\
\hline & 2004 & Wage arrears & Privatisation & - \\
\hline
\end{tabular}




\begin{tabular}{|l|l|l|l|l|}
\hline \multirow{5}{*}{ Slovakia } & 2001 & Pay & Employment & - \\
\cline { 2 - 5 } & 2002 & Labour law reforms & $\begin{array}{l}\text { Government social } \\
\text { policy and budget }\end{array}$ & - \\
\cline { 2 - 5 } & 2003 & Rail restructuring & $\begin{array}{l}\text { Overall government } \\
\text { policy }\end{array}$ & - \\
\cline { 2 - 5 } & 2004 & Transport subsidies & Pay & - \\
\hline
\end{tabular}

*First 8 months

Source: EIRO, 2005

\section{Actors and institutions: an international comparison focusing in the SME sector}

The previous sections gave a general overview of the social actors and institutions (trade unions and employers' associations, collective bargaining with a special focus on wage bargaining, employees' representation and participation, tripartite consultation and concertation bodies, etc.) which may play a benchmarking role for SMEs in relation to labour relation standards. We are aware that it is not possible to copy in a mechanical way actors and institutions of labour relations functioning in medium- and large-scale firms, therefore we suggest to use the so-called 'intelligent or reflexive benchmarking' instead of a mechanical version of it. ${ }^{4}$ The other important issue reviewed in the previous section was related to the similar and distinctive characteristics of the labour relations system between the EU-15 countries and the new Member States involved in the Leonardo Project.

The analysis of the importance and dynamism of the SME sector has frequently highlighted their significant contribution to job creation. For example, the second chapter indicated that both at the EU- and individual country-level SMEs generate at least two thirds of employment. The factors explaining the employment generating capacity of SMEs are the following:

1. Increasing share of the 'service sector' within the economy in which SMEs are dominant in comparison with the industrial sector.

4 "Reflexive benchmarking or intelligent benchmarking as it is also called is less about deciding 'what is best' or 'what universal truth' can be derived from comparison. The identification of best practice is not a primary goal of reflexive benchmarking; instead it has to do with getting to know more about various institutional solutions in different economic structures. Particularly, in a situation of fundamental transformation processes, mechanistic benchmarking is hardly possible, as institutions are becoming increasingly fragile. The aim of reflexive benchmarking is to be able to gain a better understanding of one's own solutions, their strengths and weaknesses, when seen in the light of what others do, and what options they see. Such an understanding can cause policy-makers to assess institutional solutions of their own system much more critically and may help them to deliberately imagine and act on different strategies." Schienstock. 2004: 18. 
2. The tendency for 'de-mergers' of large firms speed up of outsourcing of noncore activities, a variety of different forms of organisation disagregation became increasingly common and this process results in the shift of the importance of the SME sector.

3. SMEs are predominant in certain new economic sectors such as new media, software development, etc.

4. The dynamism of 'industrial clusters' or 'industrial districts' or 'growth poles' representing old and new forms of network type cooperation characterising both the Old and the New Economy. In this type of cooperation, SMEs are playing key role.

This is not at all a new phenomenon. 'The developing entrepreneurship pillar of the Commission's 1999 Employment Guidelines states that: «The development of new enterprises, and the growth of SMEs, is essential for hob creation. This process must be promoted by encouraging greater entrepreneurial awareness across society, by providing a clear, stable and predictable set of rules (...) The Member States should also reduce and simplify the administrative and tax burdens on SMEs.»

Despite of the intensive interest regarding SMEs, the quality of our knowledge about labour relations within this sector seems to be generally low. The aim of this section is to identify some characteristics and recent developments in the labour relation practices of SMEs, with a special focus on collective bargaining, relationships among employers and employees and employees' participations. The issues investigated include.

1. Collective bargaining coverage rate in the SMEs.

2. Employees' direct representative organisations (e.g. works council).

3. Employers' and trade unions' attitudes towards labour relations institutions: individualisation and informality of employer-employee relationship.

\subsection{Collective bargaining in the SMEs: coverage rate and procedures}

The national system of Labour Relations reviewed in the previous sections is an important factor in shaping the position of SMEs with regard to bargaining coverage. As might be expected the coverage rate of collective bargaining in the SME sector is higher in those countries which, despite the recent tendencies towards decentralisation, still have a more centralised bargaining structure, like in France, Germany and Spain participating in the Leonardo project. In these countries collective agreements signed at national or sectoral level tend to be applied in small enterprises as well as in larger ones, because such agreements may be extended to become binding on all companies in a sector, whether members of the signatory organisation or not, and regardless of size (e.g. in France). In Spain, SMEs are covered by collective agreements in the same way as other companies since sectoral agreements are applicable to all companies and workers in an industry and not only to members of the signatory 
organisations (however, labour relations experts and trade unions doubt whether sectoral agreements are actually implemented in the majority of small firms).

Following the logic of interdependency of centralised or decentralised character of the national labour relation system and the bargaining coverage rate in the SMEs, it is not surprising that the coverage rate in the SMEs is extremely low in the UK. In this country the labour relation system is voluntaristic or deregulated. When we want to quantify the bargaining coverage rate in the SME sector, only a limited amount of data is available and therefore these are scarcely comparable. This is true in the case of our project too. In spite of these methodological difficulties, we may identify the following common patterns. There is a direct relationship between the company size and collective bargaining coverage rate. As the size of the companies increases, so does the bargaining coverage rate. In the smaller firms, and especially in those with fewer than 20 employees, collective bargaining coverage is the exception. The sizecategory effect' is valid in the Hungarian case too, as an example, see the following table.

Table 14. Collective bargaining by company size (1998)

\begin{tabular}{|l|c|}
$\begin{array}{l}\text { Size categories of firms } \\
\text { (number of employees) }\end{array}$ & $\begin{array}{c}\text { Share of companies with collective } \\
\text { agreements }\end{array}$ \\
\hline $5-20$ persons & $0.1 \%$ \\
\hline $20-49$ persons & $1.1 \%$ \\
\hline $50-299$ persons & $11.7 \%$ \\
\hline $300-499$ persons & $46.4 \%$ \\
\hline $500-999$ persons & $67.3 \%$ \\
\hline 1000 and more & $75.4 \%$ \\
\hline
\end{tabular}

Source: Neumann 2002: 6

${ }^{1}$ Data on collective bargaining is often not available in the case of firms employing less than four persons.

\subsection{Collective representation structure in the SME sector: the case of works councils}

As far as the establishment of works councils is concerned, in all European countries - with the exception of Sweden - there is a minimum workforce-size threshold for the creation of this institution of participation. In the Leonardo Project countries, the lowest threshold for works councils' establishment is in Germany, with 5 employees; in France, Hungary and Spain it is 50 and in Belgium 100. In UK there is no general or statutory system of information and consultation. Beside the 'threshold' the other essential feature of works councils is the following: whether these institutions of employees' participation are established automatically in all establishments satisfying the threshold criteria or must be triggered (or initiated) by the social actors of labour relations (e.g. employees, trade unions or employers). The establishment process is basically automatic in Belgium and France but in the majority of the countries must be 
initiated by employees/trade unions; e.g. as in Hungary, Germany, Poland and Spain.

In spite the fact that the minimum size in some countries do not exist or in the majority of the countries involved in the Leonardo Project, the threshold is 5, 50 or 100 employees - these workforce-sizes are covering the small and mediumsized firms, the works councils are important participatory forum for employees in the large firms (LSE). Even the law provides basis for works councils in such countries as Germany, France, Hungary and Spain, in the SMEs only tiny minority of firms establishes works councils. "In Germany, for example, the law provides statutory rights in firms with five or more employees. The establishment of a works council is not mandatory and according to survey figures from 2002, works councils cover just $11 \%$ of all firms and $50 \%$ of all employees within the law's scope. Coverage is related to the size and the age of the firm, with smaller and newer firms much less likely to have established a works council....In France, the Ministry of Labour estimates that of small firms (10-19 employees) less than $20 \%$ have a form of workplace representation for employees. This percentage increases to $56 \%$ for firms with 20-49 employees and to $90 \%$ in firms with more than 50 employees." (Industrial Relations in Europe 2004:22.) The situation is rather similar in Hungary. However, the relation between the size of the firms and works councils call attention to another vital issue. The rate of the presence of the works councils has strong relations with the trade union presence in the firms surveyed. According to the date of a statistically representative survey carried out in 2002 in Hungary, the share of works councils, trade unions and collective agreements are indicating the similar trend: their share is increasing with the size of the firms. (See Table 15 !)

Table 15. Distribution of works councils, trade unions and collective agreements by size category of firms in the manufacturing sector in Hungary (2002)

\begin{tabular}{|c|c|c|c|c|c|c|c|}
\hline \multirow{2}{*}{$\begin{array}{l}\text { Size of the firm } \\
\text { (persons) }\end{array}$} & \multirow{2}{*}{$\mathrm{N}^{\circ}$ of responders } & \multicolumn{2}{|c|}{ Works councils } & \multicolumn{2}{|c|}{ Trade Unions } & \multicolumn{2}{|c|}{$\begin{array}{l}\text { Collective } \\
\text { agreements }\end{array}$} \\
\hline & & $\mathrm{N}^{\circ}$ & $\%$ & $\mathrm{~N}^{\circ}$ & $\%$ & $\mathrm{~N}^{\circ}$ & $\%$ \\
\hline $50-99$ & 1,082 & 288 & 27 & 261 & 26 & 243 & 23 \\
\hline $100-249$ & 882 & 456 & 52 & 389 & 46 & 359 & 41 \\
\hline Moe than 249 & 632 & 531 & 84 & 511 & 82 & 469 & 74 \\
\hline Total & 2,596 & 1,275 & & 1,161 & & 1,071 & \\
\hline
\end{tabular}

Source: Benyó, B. A munkavállalói részvétel intézménye: az üzemi tanácsok helyzete Magyarországon, (Institution of Emplyees' Participation: Situation of Works Councils in Hungary), PhD Dissertation, Budapest: Budapest University of Economic Sciences and Business Administration - Department of Social Policy and Sociology, p.75. 


\subsection{Employers' (employers' organisations') and trade unions' attitudes towards labour relation institutions in the SME sector}

Employers' organisations generally view favourably the fact that small firms, unlike their larger counterparts, represent a high level of flexibility in regulating the employment relationship. This high level of flexibility is the main factor responsible for their economic success. Employers' organisations are in favour of even further deregulation of SMEs. See two examples of this attitude of employers' organisations towards SMEs in the following box.

\section{Box 4. Employers' organisations and SMEs}

Most UK employers' associations have traditionally preferred a deregulatory approach to industrial relations. Since the current Labour Party government made public in 1998 its various proposals for legislation to provide a minimum floor of employment rights, employers' associations have lobbied for the legislation to be watered down, especially where it applies to SMEs. Thus, for instance, firms with under 20 employees have been removed from the scope of proposed trade union recognition regulations.

In France, employers' organisations, and particularly the SME-specific CGPME, have demanded that social security contributions levied on SMEs should be reduced, and that they should be given more flexibility by alleviating their legal obligations, simplifying bureaucratic procedures, and raising the thresholds for obligatory employee representation.

Source: EIRO 1999: 10

However, in some cases the employers are positive towards trade union activities, especially in sectors which have a strong institutional heritage of collective interest representation, as shown by the example of a Belgian employer operating in the construction sector:

\section{Box 5. Belgian construction sector company, 100 employees}

"I totally agree that my workers are members of a trade union. They need to have their rights defended. But dialogue needs to be always the main way of communication. In our company there are also many ways of informal contact; we go and have a drink together regularly, for instance. There is an open atmosphere." (owner/employer)

In spite of the favourable opinion of employers' organisations concerning small firms, these associations have various problems in the SME sector. In terms of their own membership among the SMEs, mainstream employers' organisations often face several problems. For example, in Germany a key issue is the representation of the interests of SMEs. According to the survey results, important segments of the small firm sector feel that they are not represented in the traditional employers' associations. 
In relation to the trade unions' attitudes towards SMEs, the mainstream opinion is as follows. They have difficulties in creating both workplace interest representation institutions (e.g. collective bargaining) and employees' participation structure (e.g. works councils) especially in smaller firms. The opinion of a Hungarian trade union leader interviewed in the clothing industry sector summarises well the difficulties of implementing collective interest representation structures in the workplace in the post-socialist economies of the NMS countries.

\section{Box 6. Hungarian trade union of workers in the Garment trade}

"When big clothes factories closed down many people registered themselves for unemployment benefit, but at the same time they started working in the black economy. It is hard to make these people understand what disadvantages they can suffer without being registered employees because until they have no other alternatives they will not leave their black sector job. Frightening them with the ghost of being without a pension and health insurance is fairly useless until they are forced somehow to deal with this question. Many of those who are employed in the black economy are retired or have this as a part-time or a second job. This system works reasonably well as long as employers pay correctly, but alongside this there are many unstable elements. (...) The badly defined job contracts and unregistered salaries press employers to exclude any third party from the relationship between themselves and the employees. This often leads to the high vulnerability of workers. "Many people who contact us report delayed or unpaid salaries." (Vice President)

In addition, in the case of post-socialist (NMS) countries involved in the Leonardo project, the company case studies indicated intention of owners/managers of small firms to individualise employment relationships with their workers was in line with the ambition of their employees too. This latter phenomenon can be attributed to employees' lack of trust towards their trade unions and due to the informal character of the employer-employee relationship.

In relation to the trade unions' role in the SME sector, the issue of worker protection in smaller firms is important in the EU-15 countries too. For example, Belgian trade unions are seeking to have the thresholds for the creation of various representative structures or the application of other employment rights lowered. It is interesting to note that the French trade unions are acting to reduce inequalities of working an employment conditions between employees of SMEs and larger sized companies. In the UK the Trade Union Council (TUC) has campaigned during the 1980s and 1990s for the establishment of minimum standards in the work place, including for SMEs. Another recent British initiative to strengthen the trade union presence at firm level is the Union Learning Fund (ULF). This fund was established in 1998 by the new Labour Government with the purpose of involving trade unions in the government's lifelong learning programme. Money is provided that generates capacity- 
building by these trade unions to encourage and enable learning that promotes employability and inclusion for individuals, and helps employers with productivity and competitiveness. The most obvious manifestation of this capacity-building has been the creation of Union Learning Representatives (ULRs), who, since 2002, have the same rights as other workplace trade union representatives, such as shop stewards. Working with employers, the function of these ULRs is to facilitate and encourage employees to participate in learning. It has been suggested that these ULRs offer "potentially the most significant statutory role for workplace unionism since the recognition of health and safety representatives in the mid-1970s [and] may have the potential for furthering union revitalisation." (Warhurst 2005:2)

For the opinion of employers and employees on Labour Relation institutions, see the following box containing quotations from the company case studies.

The interviews quoted above from the company case studies indicate the low awareness or the lack of need both on the part of employers and employees for the establishment and role of official institutions and collective actors of Labour Relations. The lack of official institutions of labour relations does not mean a lack of social consent between the actors involved in the labour process. In other words, we have to stress the informality of employment relations and the rather paternalistic pattern of management in the firms surveyed. In addition we have to note that in the ICT sector where the smooth communication and the employees expressed their interest in a more intensive participation in the workrelated decision-making. For example, the lack of involvement which employees criticised in the managerial decisions is reflected by the following opinion of a manager working in the Hungarian interactive media company.

\section{Conclusions}

The presentation of the main actors and institutions of Labour Relations System (LRS) is in the focus of analysis carried out in this paper.

Comparing the key patterns of LRS at European level, it is worth noting that in the majority of countries - with the exception of the U.K. - the so-called 'dualchannel system' is functioning; in addition to the trade unions a separate institution of employees' participation does exist. In relation with the trade union membership ('density rate') the highest rate was registered in Belgium $(55.8 \%)$ and the lowest in France $(9.7 \%)$. For the trade union structure ('organisational comprehensiveness') single or dominant peak organisation (confederation) were found in Germany, Slovakia and the U.K. In the remaining countries fragmented union structure (by occupation and political divide) was identified. 
Box 7. Mixed opinions of employers and employess on the firm level labour relations is selected contries:

\section{Polish ICT firm, 120 employees}

There are no trade unions in the firm (and never were). In the intervewee's opinion, there is no need for the existence of such a representation for employees, because "as the employers, we try to fulfill our obligations towards our employees consistently". The owner thinks that trade unions should function; however, "they should be created outside the firm's structures". There are neither informal employees' groups nor individuals representing the whole staff.

\section{Polish funeral service firm, 64 employees}

No workers' organization exists in the enterprise; there are no trade unions. Trade unions are viewed by the owner as a threat to the functioning of the enterprise ("If there were trade unions I would have to finish my activity. Firstly, the firm is too small, and secondly, it could not survive the trade unionists ' economic demands"). The existence of trade unions is also viewed as an obstacle in the present functioning of the firm ("If trade unions had developed, I would have to negotiate, discuss things etc. I would not be able to concentrate on the firm's management"). At the same time, there is no representative of the whole staff of the enterprise. The entrepreneur is of the opinion that maintaining individual contacts with all the employees is sufficient.

\section{Polish tourist company, 23 employees}

The company studied has no official trade union representation. There is also no one who, informally, might represent the staff. It is the view of the owner that there is neither such a need nor any desire on the part of employees. "This is a small company. Employees can turn to me at any time. The door is always open for them. Moreover, they are all aware of the fact that I did not build this company at their expense, at the expense of their earnings. I meet my obligations with respect to employees 100\%." (owner/employer)

\section{Hungarian clothing company, 6 employees}

The following opinion can be said to be typical: "I do not think we need trade unions, we can handle things informally. If we cannot we can still quit and choose to be home-workers." (employee, sewer) 


\section{Spanish food company, 165 employees on average, but 320 in the summer season \\ "At the moment, we don't have any conflict. Over the five years that I've been here, there hasn't been any conflict on the labour level. There is no trade union. I don't know if this gives us advantages or not. The CCOO, the UGT have been here... but they didn't hold a meeting. Sometimes this brings us problems in respect of labour risks... I'm not going to tell you that the relations are too good, because nothing is ever too good, but we can't complain and this is also reflected in the proper working of the company. On a labour level, the company works extremely well and also, more than ever, in one of the most important aspects: the daily working atmosphere. We also have to bear in mind that this is a small town. The people who work here are familiar, they know each other... and it's normal for there to be a relationship on the work level and also on the level of the town. An influencing factor in the good atmosphere is that the friendly atmosphere has always been here" (employer)}

\section{Spanish tourist company, 3 employees}

"Mónica and I don't have what you would call a purely boss-employee relationship. We worked together at another company for some time, so our relationship is more like two heads are better than one. And together we will be able to achieve more than a single person. There is a lot of trust and confidence, and I've asked her opinion on all of the changes that I have thought about making, and other times she has convinced me that it would be better to do something else that I hadn't thought of. I think that the relationship has to be like that. It doesn't mean that if everything up until now has been white, it is now going to be green. And I even think that it is better for her. Since we spend so many hours together and have hit it off so well, when she has to do something, she doesn't have to ask my permission or ask what I think if she does it - the final cause is going to be the same as if I had decided myself. She has demonstrated to me that she is a total professional and knows how to do things, and I have full confidence in whatever she does" (owner/employer)

Box 8. Hungarian ICT company, 62 employees

"Compared with my previous workplace it is a very bad thing that here we don't know where we are going. We give a lot of information to the management, but they inform us sometimes just at the last minute. Often in a given situation we don't know what to do to help the company's long-term aims." (digital media manager) 
In this relation it is necessary to mention that trade union movement in the EU15 countries is characterised by the trend of merger, while in the NMS it is still de-concentration and fragmentation take place. Similar pattern was observed in the employers' side in concentrating functions to improve the quality of services of their member organisations. Collective bargaining (CB) is the core institution of the LRS which shows stability and the coverage rate of which is twice as high than the union density rate. The $\mathrm{CB}$ coverage rate is higher in the EU-15 countries in comparison with the countries in the NMS. Evaluating the key source of the European wide industrial dispute we may say that wages or salaries are in the centre of conflicts between employers and employees and their respective interest representative associations. As a result of the decentralisation of LRS in the last decades, the 'locus' of the wage-bargaining is the firm. This pattern is similar between EU-15 and NMS, with the exception of Slovakia. Beside the decentralisation of wage bargaining, we have to call the attention to another important characteristic of the wage bargaining: the explicit or implicit form of its coordination. In this respect the following three groups should be distinguished: only Belgium maintained and reintroduced some forms of explicit coordination at national level, in Germany and Spain - where central agreements have set guidelines for wage conduct since 2001 - the implicit coordination has taken place between the social partners. Implicit coordination characterises the French wage-bargaining procedures. Finally, in the U.K., similarly to Poland, both national and sector level coordination are missing.

In relation with the national level concertation and consultation, variety of institutional arrangements was found in countries surveyed. The government intervention is the strongest in France and the weakest in the U.K. The government, trade unions and employers' national level representative bodies dealing with consultation, may take the form of bipartite, tripartite or a wider participation. In the EU-15 countries, the presence of the national bodies for consultation and representation is general. In the majority of cases, participation in such institutions is practiced by national peak associations of both trade unions and employers' organisations. The statutory bodies which could be bipartite, tripartite etc. deal with general issues (e.g. in Belgium and Hungary) or specific issues such as social security administration (e.g. in France and Germany) or with the application of labour law and extension of collective agreements (as in the case of Germany).

The 'industrial actions' mentioned above are highly sensible characteristic of the LRS. However, the intensity of industrial actions in itself does not reflect automatically a malfunctioning labour relations system. The indicator such as number of working days lost by strikes per 1000 employees expresses functional distortion in this system. Comparing the available indicators (in the year of investigation: 2004) in the countries participating in the Project the following rank-of-order was identified: (1) Spain (219.7 days), (2) Hungary (60.2 days), 
France (50.5 days), the UK: (27.5 days) and finally Germany (4 days) and Poland ( 2 days). When comparing countries characterised by the broadly comparable size, the 'big four' old EU countries (France, Germany, Spain and the U.K.) are representing at least two groups of countries: Spain has a considerably higher frequency of industrial actions in comparison with France, the U.K. and Germany. However, it is necessary to note that even in Spain, a rapid decline in working days lost by strikes was registered in the period between 2002 and 2003 and this fall is continuing.

Describing the roles of LRS in the SME sector - both European and country level - special attention was devoted to issues such as collective bargaining, collective representation and the attitudes of employers and trade unions towards to the LRS. Firstly, we intend to stress that there is a direct relationship between the company size and collective bargaining coverage rate: as the size of firm increases, so does the bargaining coverage rate. In the smaller firms, especially in those with fewer than 20 employees, collective agreements are exception. Secondly, in the case of such institution of employees' collective representation - with the exception of Sweden - in all EU-15 countries there is a minimumworkforce-size threshold for establishment of Works Councils (WC). In relation with the countries participating in the Leonardo Project, the lowest threshold for the creation of WC is in Germany: 5 employees, followed by France, Hungary and Spain with 50 employees and in Belgium 100. In the U.K. there is no general or statutory system of information and consultation. Additionally, it is worth noting that beside the size of the firm, the acceptance of WC has a close relationship with the presence of trade unions in the firm. Finally, in relation with the employers' attitudes towards trade unions, we may say that they prefer the flexible employment relations - as a main source of their economic success and have rather unfavourable opinions. In the company case studies the positive employers' opinion on the trade union presence was the exception. Even some cases, employees themselves have rather ambivalent opinion on the necessity of the trade unions on the workplace. Instead, they preferred the individual and informal arrangements based social consent with the employers which is consistent with the „paternalistic style” of management in the firms surveyed.

\section{ANNEX 1 LEONARDO Community Vocational Training Action Programme,}

(2003-3448/001-001-LE2_OREF, Contract start date: 01. October 2003, Duration 36 Months (01. 10. 2003 - 30. 09. 2006)

\section{Partners:}

Belgium: $\quad$ EHSAL, Brussels

France:

Université Paris X, Nanterre 
Germany:

Wismar University; Wismar

Hungary:

Institute of Sociology, Hungarian Academy of Sciences; Budapest

Poland:

Institute of Labour and Social Studies; Warsaw

Spain:

UNED; Madrid

Slovakia:

Institute for Sociology, Slovak Academy of Sciences; Bratislava

UK: $\quad$ University of Luton, Luton

\section{References}

Addison, J.T./Schnabel, C.(2003): International handbook of trade unions, Cheltenham: Edgar Elgar.

Adler, P./Kwon, S.W.(2000): Social capital: the good, the bad and the ugly, in: Lesser, E. L. (ed): knowledge and social capital (Foundations and Applications), Oxford: Butterworth Heinemann.

Benyó, B.(2004): A munkavállalói részvétel intézménye: az üzemi tanácsok helyzete Magyarországon, (Institution of Employees' Participation: Situation of Works Councils in Hungary), PhD Dissertation, Budapest: Budapest University of Economic Sciences and Business Administration - Department of Social Policy and Sociology.

Boeri, T./Brugiavini, A./Calmfors, L. (eds.): The role of the trade unions in the $21^{\text {st }}$ Century, Oxford: Oxford University Press.

Charley, M./Baradel, A./Welz, Ch.(2004): Works councils - Workplace representation and participation structures, EIRO Thematic Features, Dublin: European Foundation for the Improvement of Living and Working Conditions.

Crouch, C. J./F. Traxler, F.(eds.) (1995): Organised Industrial Relations in Europe. What future?, Hants, Vermont.Damijan, J.P./Knell, M./Majcen, B./Rojec, M.(2003): The role of FDI, R\&D accumulation and trade in transferring technology to transition countries: evidence from firm panel data for eight transition countries Economic Systems 27, 2, 189-204.

Developments in industrial actions: 2000-2004, http://www.eiro.eurofound.eu.int/2005/06/update/tn0506101u.htm.

Ebbinghaus, B./Visser, J.(2000): The societies of Europe. Trade Unions in Western Europe since 1945, London: Plagrave.

Ebbinghaus, B./Visser, J.(1999): When institutions matter: Union growth and decline in Western Europe, 1950-1995, European Sociological Review, 15.

EIRO (1999): Industrial relations in SMEs.

http://www.eiro.eurofound.eu.int/1999/05/study/tn9905201s.html.

date of downloading: $12^{\text {th }}$ September 2005. 
Employment relations in micro and small Enterprieses in the EU - Literature Review (2002) Dublin: European foundations for the improvement of living and working conditions Main results.

European foundation for the improvement of living and working conditions and its European industrial relations observatory online (Euroline), http://www.eiro.eurofound.

Foglalkoztatáspolitikai és Munkaügyi Minisztérium (2004) Ágazati párbeszéd bizottságok Magyarországon (Sector level social dialogue committees), Budapest: Foglalkoztatáspolitikai és Munkaügyi Minisztérium.

Industrial relations in Europe 2004, EC DG for employment and social affairs, Unit D1, Luxemburg: Office for Official Publications of the European Communities.

Industrial relations in SMEs, EIRO http://www.eiro.eurofound.eu.int/1999/05/study/tn9905201s.html.

Lesser, E.L.(2000): Leveraging social capital in organizations, in: Lesser, E. L. (ed): Knowledge and social capital (Foundations and Applications), Oxford: Butterworth Heinemann.

Lindbeck, A./Snower, D.J.(2001): Centralised bargaining and reorganised work: Are they compatible?, in: European Economic Review, 45.

Makó, Cs.(2001): A magyar munkaügyi kapcsolatok duális karaktere, (A munkavállalói részvétel intézménye és az európai perspektíva), (The dual character of Hungarian labour relations - institution of employees' Participation in a European perspective), Társadalomkutatás, (2001), 3, 4, 145-169.

Makó, Cs./Novoszáth, P.(1995): Employment relations in multinational companies: the Hungarian case, in: Dittrich, E./Schmidt, G./Whitley, R. (eds.) (1995) Industrial transformation in Europe: process and context, London: Sage Publication, 255-277.

Makó, Cs./Novoszáth, P./Veréb, Á.(1998): Átalakuló munkaerőfelhasználási minták és a vállalati munkaügyi kapcsolatok, (Munkavállalói beállítottságok nemzetközi összehasonlításban), (Changing Patterns of Manpower Use and Firm-Level Labour Relations, Workers' Attitude in an International Comparison). Budapest: Aula Kiadó, 208.

Makó, Cs./Simonyi, Á.(1997): Inheritance, imitation and genuine solutions, (Institution Building in Hungarian -Labour Relations), in: Europe-Asia Studies,(1997) 49, 2, 221244.

Makó, Cs./Simonyi, Á.(2003): A munka és párbeszéd új paradigmái (New Paradigmes of Work and Social Dialogue). Budapest: National Employment Fund.

Neumann, L.(2002): EIRO Comparative Study on Collective Bargaining Coverage and Extension Procedures - Case of Hungary. Budapest: Insitute of Labour - Ministry of Employment and Labour.

Neumann, L.(2003): The impact of European legislation on an accession country's labour relations (The Case of Hungarian Transposition of Undertaking Directive). Paper presented for IIRA $13^{\text {th }}$ in: World Congress, Berlin.

Neumann, L.(2005): Towards trade union strategy for decent work - the Hungarian Case. Budapest: Institute of Labour Research, Mimeo. 
Read, I.(2005) Employers' association and SME interests in the UK, London: Metropolitan University - Working Lives Research Institute.

Rogers, J./Streeck, W.(eds.)(1995): Works councils, consultation, representation and cooperation in industrial relations, Chicago: University of Chicago Press.

Schienstock, G.(2004): From path dependency to path creation: a new challange to the systems of innovation approach, in: Schienstock, G. (ed.) Embracing the Knowledge Economy: The Dynamic Transformation of the Finnish Innovation System, Cheltenham, UK: Edward Elgar Publishing Ltd, 3-27.

Schulte, B./Guillén, M./Tsakloglou, P./Katrougalos, G./Wilthagen, T./Bradsaw, J./Anxo, D./Ericson, T.(2003): Flexibility and social protection - European foundation for the improvement of living and working conditions, Luxemburg: office for official publications of the European communities.

Thelen, K./Kune, I.(2003): The future of nationally embedded capitalism, industrial relations in Germany and Japan, in: Yamamura - in: Streeck (eds.) The end of diversity. Prospects for German and Japanese capitalism, Ithaca, N.Y.: Cornell University Press.

Traxler, F.(2003): Bargaining, state regulation and the trajectories of industrial relations, in: European Journal of Industrial Relations, 9, 141-161.

Traxler, F.(2003): Bargaining (De)centralization, macroeconomic performance and control over the employment relationship, in: British Journal of Industrial Relations, 41, 1-28.

Traxler, F.(2003): Bargaining institutions and the monetary regime: A cross-national comparison and its implications for European Monetary Union, in: Journal of European Public Policy, 10, 596-615.

Traxler, F./Behrens, M.(2002): Collective bargaining coverage and extension procedures, EIRO - Eironline; Wage-Setting Institutins, Employment Outlook, Paris, no. 17.

Traxler, F./Blaschke, S./Kittel, B.(2001): National labour relations in Internationalised market. A comparative study of institutions, change and performance, Oxford: Oxford University Press.

Yamamura, K./Streeck, W.(eds.) (2003): The end of diversity. prospects for German and Japanese capitalism, Ithaca, N.Y.: Cornell University Press.

Van, G.(2003): Industrial relations as a key to strengthening innovation in Europe, EC directorate-general for enterprise - EUR 17060, in: Innovation Papers 36, Luxemburg.

Vielle, P./Walthery, P.(2003): Flexibility and social protection, The European foundation for the improvement of living and working conditions, Luxembourg: Office for Official Publications of the European Communities.

Visser, J.(2002): Why fewer European workers join Unions. A social customs explanation of membership trends, in: British Journal of Industrial Relations, 40.

Warhurst, Ch.(2005): The UK Union learning fund - A briefing note for the deputy minister of labour, Hungary. Glasgow: Scottish Centre for Employment Research - Department of Human Resource Management University of Strathclyde.

Wim K.(2003): Report of the employment workforce, Jobs, Jobs, Jobs: Creating more employment in Europe, Luxemburg: Office for Official Publications of the European Communities. 